\title{
Analisis Kebutuhan Bahan Ajar Matematika Dasar untuk Mahasiswa
}

\author{
Alfi Yunita ${ }^{1 *}$, Hamdunah $^{2}$, Anny Sovia ${ }^{3}$ \\ 1,2,3 STKIP PGRI Sumatera Barat \\ *alfi_yunita@ymail.com
}

Diterima: September 2019. Disetujui: Desember 2019. Dipublikasikan: Januari 2020

\begin{abstract}
ABSTRAK
Matematika dasar merupakan salah satu mata kuliah wajib bagi sebagian program studi di STKIP PGRI Sumatera Barat. Penelitian ini bertujuan untuk menganalisis kebutuhan mahasiswa STKIP PGRI Sumatera Barat terhadap bahan ajar pada perkuliahan matematika dasar. Penelitian dilakukan melalui survei terhadap 88 mahasiswa yang terdiri atas 31 mahasiswa dari program studi pendidikan Fisika dan 57 mahasiswa dari program studi pendidikan biologi. Sampel diambil purposif, yaitu mahasiswa yang sudah berada dikelas lanjutan. Instrumen yang digunakan pada penelitian ini adalah lembar analisis, berupa angket, dan pedoman wawancara. Angket diberikan kepada mahasiswa program studi Pendidikan Fisika dan Pendidikan Biologi. Data angket dan wawancara dianalisis secara kualitatif. Hasil penelitian ini menunjukkan bahwa mahasiswa membutuhkan buku teks bilingual dengan pendekatan konstruktivisme pada perkuliahan matematika dasar.

Kata kunci: bahan ajar, matematika dasar.
\end{abstract}

\section{ABSTRACT}

Basic mathematics is one of the compulsory subjects for some courses in STKIP PGRI Sumatera Barat. This research aims to analyze the needs of students STKIP PGRI Sumatera Barat on teaching materials on basic mathematics lectures. The study was conducted through a survey of 88 student of advanced classes, consisting of 31 students from Physics education program and 57 students from biology education program were selected through purposive sampling. The instruments used in this research are the analysis sheet, in the form of questionnaires, and interview guidelines. Questionnaire and interview data were analyzed qualitatively. The results of this research indicate that students need bilingual textbooks with a constructivism approach in basic mathematics lectures.

Keywords: teaching materials, basic mathematics.

How to Cite: Yunita, A., Hamdunah, \& Sovia, A. (2020). Analisis Kebutuhan Bahan Ajar Matematika Dasar untuk Mahasiswa. Journal of Medives: Journal of Mathematics Education IKIP Veteran Semarang, 4(1), 23-36. 


\section{PENDAHULUAN}

Matematika dasar merupakan salah satu mata kuliah wajib bagi mahasiswa program studi pendidikan biologi dan pendidikan fisika di STKIP PGRI Sumatera Barat. Profil lulusan mahasiswa di STKIP PGRI Sumatera Baratsalah satunya adalah menjadi seorang guru. Matematika sangat diperlukan baik itu untuk calon guru matematika maupun calon guru mata pelajaran lain.Materi dalam mata kuliah matematika dasar ini meliputi sistem bilangan riil, ketaksamaan dan nilai mutlak, fungsi dan grafik fungsi, sistem persamaan linier dan nonlinier, trigonometri, geometri, statistika, peluang, barisan dan deret, limit dan kekontinuan, turunan dan integral. Kegagalan mahasiswa dalam mempelajari mata kuliah matematika dasar didasari oleh mahasiswa hanya cenderung menghafalkan konsep dan rumus yang dipelajari tanpa memahami dengan benar, kurangnya motivasi untuk mengulang kembali materi dan menyelesaikan tugas di rumah. Jika diberikan soal yang berbeda dengan contoh soal yang diberikan.

Selain itu pendekatan yang dilakukan oleh dosen belum mampu mengembangkan kemampuan penalaran, afektif, dan keterampilan akibatnya penguasaan terhadap konsep-konsep dalam mata kuliah matematika dasar menjadi sangat kurang.

Hal ini terlihat pada nilai UAS (Ujian Akhir Semester) mahasiswa Program studi pendidikan Fisika dan mahasiswa program studi pendidikan Biologi pada Tahun Ajaran 2016/2017 dimana persentase jumlah mahasiswa yang mendapatkan nilai lebih dari 65 adalah sebesar 38,63\% dari 88 mahasiswa. Persentase ini belum memenuhi standar pencapaian yang ditetapkan di STKIP PGRI Sumatera Barat, yakni sebesar 70\%. Oleh karena itu, dapat dikatakan bahwa mahasiswa belum memahami konsep dengan baik.

Menurut Murtiyasa (2015), ASEAN Economics Community atau MEA, yang merupakan singkatan dari Masyarakat Ekonomi ASEAN, memiliki pola mengintegrasikan ekonomi ASEAN dengan cara membentuk sistem perdagangan bebas atau free trade antara negara-negara anggota ASEAN. Para anggota ASEAN termasuk Indonesia telah menyepakati suatu perjanjian Masyarakat Ekonomi ASEAN tersebut. MEA akan mulai membentuk ASEAN menjadi pasar dan basis dari produksi tunggal yang dapat membuat ASEAN terlihat dinamis dan dapat bersaing dengan adanya mekanisme dan langkahlangkah dalam memperkuat pelaksanaan baru yang berinisiatif ekonomi; mempercepat perpaduan regional yang ada disektor-sektor prioritas; memberikan fasilitas terhadap gerakan bisnis, tenaga kerja memiliki bakat dan terampil; dapat memperkuat kelembagaan mekanisme di ASEAN. Menjadi langkah awal dalam mewujudkan MEA atau Masyarakat Ekonomi ASEAN.

Menghadapi MEA, Kementrian Pendidikan dan Kebudayaan (Kemendikbud) juga menghimbau guru Indonesia untuk memiliki daya saing yang tinggi. Salah satu penunjang agar guru memiliki daya saing yang tinggi adalah setiap guru mampu berbahasa Inggris dan mahir dalam ilmu matematika. Bahasa Inggris merupakan bahasa 
internasional yang umum digunakan oleh Masyarakat Ekonomi ASEAN sehingga matematika mempunyai peran yang penting dalam pengembangan berbagaidisiplin ilmu. Mahasiswa di STKIP PGRI Sumatera Barat adalah calon guru yang diharuskan mampu bersaing dengan calon guru lainnya baik dari negara Indonesia maupun guru dari luar negeri. Kompetensi yang harus disiapkan untuk menghadapi MEA di antaranya adalah komunikasi dalam bahasa Inggris. Salah satu cara untuk meningkatkan kemampuan bahasa Inggris mahasiswa adalah dengan menggunakan buku-buku teks berbahasa Inggris dalam perkuliahan.

Peraturan Menteri Pendidikan Nasional Nomor 11 Tahun 2005 menjelaskan bahwa buku teks adalah buku acuan wajib untuk digunakan di sekolah yang memuat materi pembelajaran dalam rangka peningkatan keimanan dan ketakwaan, budi pekerti dan kepribadian, kemampuan penguasaan ilmu pengetahuan dan teknologi, kepekaan dan kemampuan estetis, serta potensi fisik dan kesehatan yang disusun berdasarkan standar nasional pendidikan. Pusat perbukuan dalam Muslich (2008) menyimpulkan bahwa buku teks adalah buku yang dijadikan pegangan siswa pada jenjang tertentu sebagai media pembelajaran (instruksional), berkaitan dengan bidang studi tertentu. Berdasarkan hal tersebut, buku teks merupakan buku standar yang disusun oleh pakar dalam bidangnya, bisa dilengkapi sarana pembelajaran (seperti rekaman) dan digunakan sebagai penunjang program pembelajaran.
Ansary \& Babaii (2002) secara detail menjelaskan unsur-unsur penggunaan buku teks sebagai berikut. Pertama, buku teks merupakan kerangka kerja yang mengatur dan menjadwalkan waktu kegiatan program pengajaran. Kedua, di mata siswa tidak ada buku teks berarti tidak ada tujuan. Ketiga, tanpa buku teks, siswa mengira bahwa mereka ditangani secara serius. Keempat, dalam banyak situasi buku teks berperan sebagai silabus. Kelima, buku teks menyediakan teks pengajaran. Kelima, buku teks menyediakan teks pengajaran dan tugas pembelajaran yang siap dipakai. Keenam, buku teks merupakan cara yang paling mudah untuk menyediakan bahan pembelajaran. Ketujuh, siswa tidak mempunyai fokus yang jelas tanpa adanya buku teks dan ketergantungan pada guru menjadi tinggi. Kedelapan, bagi guru baru yang kurang berpengalaman, buku teks berarti keamanan, petunjuk, dan bantuan. Hal ini menunjukkan bahwa buku teks mempunyai peranan penting dalam proses pembelajaran.

Menurut Altbach, Kelly, Petrie, \& Weis (1991) Textbooks are a central part of any education system. They help to define the curriculum and can either significantly help or hinder the teacher. Berdasarkan pendapat tersebut, diketahui bahwa buku teks merupakan sebuah bagian utama dari beberapa sistem pendidikan yang membantu untuk memaparkan hal yang terdapat dalam kurikulum dan dapat menjadi bantuan yang jelas bagi pendidik dalam melaksanakan pembelajaran, salah satunya pembelajaran matematika dasar. 
Saat ini belum ada buku teks yang bisa mengkonstruksi pengetahuan mahasiswa dengan baik untuk belajar matematika dasar dalam dua bahasa (bilingual). Pembelajaran bilingual adalah suatu pembelajaran pada mata pelajaranmata pelajaran yang dilakukan menggunakan dua bahasa yang berbeda (Wikipedia, 2017). Senada dengan pendapat tersebut, Depdiknas (2007) memberikan batasan pembelajaran bilingual sebagai pembelajaran yang materi pelajaran, proses belajar mengajar, dan penilaiannya menggunakan bahasa Indonesia dan Bahasa Inggris. Selain itu, Supriyadi (2012) juga menegaskan bahwa pembelajaran bilingual dapat meningkatkan aktivitas dan motivasi mahasiswa dalam belajar. Tujuan pembelajaran berbasis bilingual adalah agar mahasiswa mampu menguasai dua bahasa yaitu bahasa ibu (bahasa asal) dan bahasa asing sebagai bahasa pengantar. Dengan penguasaan dua bahasa ini diharapkan akan mempengaruhi identitas anak didik di tempat kerja, kehidupan sosial, maupun dalam cara berpikirnya. Oleh karena itu, dengan adanya buku teks bilingual dapat mendukung perkuliahan dalam dua bahasa dan dapat meningkatkan kemampuan matematis mahasiswa.

Menurut Murtiyasa (2015), tren materi matematika merujuk pada standar internasional baik itu PISA maupun TIMSS, baik itu dalam hal keluasan maupun kedalaman. Indonesia salah satu negara yang telah memperbaharui pelajaran matematika dengan memperbarui kurikulum yaitu menjadi kurikulum 2013 yang merujuk pada TIMSS dan PISA. Untuk menunjang peningkatan pemahaman mahasiswa terhadap matematika maka diperlukan suatu pendekatan pembelajaran yang berdasarkan atas kurikulum 2013.

Pendekatan pembelajaran yang merujuk pada kurikulum 2013 dalam pembelajaran matematika yaitu pendekatan konstruktivisme. Barlia (2011) menyebutkan bahwa konstruktivisme didasari oleh pemikiran bahwa peserta didik memperoleh dan membentuk pengetahuan secara alami. Artinya, mereka membentuk pengetahuan berdasarkan pengalaman dirinya dengan caranya sendiri sesuai dengan karakter perkembangan intelektual pada usianya. Dalam kurikulum 2013 dikenal dengan pendekatan saintifik, yang sebenarnya merupakan implementasi dari teori belajar kontruktivisme. Prinsip-prinsip konstruktivisme di antaranya meliputi: (1) pengetahuan dibangun oleh siswa sendiri, (2) pengetahuan tidak dapat dipindahkan dari guru ke murid, (3) murid aktif mengkontruksi secara terus menerus, sehingga selalu terjadi perubahan konsep ilmiah, (4) guru sekedar membantu menyediakan sarana dan situasi agar proses konstruksi berjalan lancar. Dengan adanya pembelajaran matematika dasar dengan pendekatan konstruktivisme diharapkan mahasiswa bisa memahami materi baik dan dapat meningkatkan kemampuan matematis mahasiswa tersebut.

Driver \& Oldham (1986) menjelaskan bahwa mengajar berdasarkan konstruktivisme dilakukan dengan beberapa tahap. Pertama: orientasi, anak didik diberi kesempatan untuk mengembangkan rasa ingin tahu atau membawa pemikirannya kepada tujuan dan 
motivasi untuk belajar topik tersebut. Tahap berikutnya adalah elisitasi, yaitu mengajak anak didik untuk memikirkan dan mengeluarkan pemikiran-pemikiran terbarunya tentang topik yang akan diajarkan, untuk memperjelas pelajaran tersebut, dilakukan melalui macammacam aktivitas seperti diskusi kelompok, membuat poster atau tulisan. Restrukturisasi ide-ide merupakan inti dari proses kegiatan pembelajaran berdasarkan konstruktivisme, meliputi beberapa tahap, yaitu: klarifikasi danpertukaran ide-ide. Dalam tahapan ini, pengertian atau pengetahuan tentang sesuatu yang dipunyai anak didik, dan bahasa yang digunakannya diperjelas, dipertajam dan dikontraskan dengan yang lain atau dipertentangkan dengan pandangan atau pendapat siswa lain atau dengan pendapat guru. Selanjutnya, dilakukan pembentukan ide-ide baru berdasarkan hasil diskusi yang dilakukan, dilanjutkan dengan mendemonstrasikannya. Tahap berikutnya dilakukan evaluasi ide-ide baru, baik dengan cara eksperimen atau dengan berpikir tentang implikasi-implikasinya. Review, merupakan tahap akhir dari kegiatan pembelajaran, di mana anak didik dituntut untuk merefleksikan kembali ide-idenya. Ideide mereka mungkin berubah. Untuk mengetahui perubahan ide-ide tersebut, dilakukan dengan membuat perbandingan antara pemikiran awal dan akhir, selama mereka mengikuti proses pembelajaran. Tahapan pembelajaran konstruktivisme merupakan tahapan pembelajaran yang terstruktur untuk mengkonstruksi pengetahuan anak didik. Pendekatan ini dapat pula dituangkan dalam bentuk bahan ajar, seperti buku teks dengan tetap memperhatikan prinsip-prinsip dan tahapan konstruktivisme. Dalam penelitian yang dilakukan oleh Hamdunah, Yunita, Zulkardi, \& Muhafzan (2016) bahwa pendekatan konstruktivisme merupakan salah satu alternatif yang digunakan untuk meningkatkan hasil belajar mahasiswa Program Studi Pendidikan Matematika STKIP PGRI Sumatera Barat pada Mata Kuliah Geometri Analitik, dalam penelitian terdahulu telah menghasilkan modul konstruktivisme yang valid, praktis dan efektif untuk materi lingkaran dan bola dengan bantuan program wingeom.

Berdasarkan uraian dari permasalahan yang telah dikemukakan di atas, diperlukan pengembangan buku teks bilingual untuk mata kuliah Matematika Dasar dengan pendekatan konstruktivisme di STKIP PGRI Sumatera Barat. Untuk mengembangkan buku teks bilingual dengan pendekatan konstruktivisme tersebut diperlukan data-data hasil analisis kebutuhan mahasiswa terhadap buku teks bilingual dengan pendekatan konstruktivisme.

\section{METODE PENELITIAN}

Penelitian ini merupakan penelitian pengembangan (Research \& Development) dengan model ADDIE dengan tahapannya terdiri atas tahap analisis (analyze), yaitu melihat gambaran kondisi di lapangan yang berkaitan dengan proses belajar mengajar. Tahap desain (design), yaitu merancang buku teks dengan pendekatan konstruktivisme. Tahap pengembangan (develop) adalah adalah memvalidasi buku teks bilingual. Tahap implementasi (imple- 
ment) merupakan tahap uji praktikalitas buku teks bilingual. Tahap evaluasi (evaluate) adalah tahap penilaian terhadap keefektifan produk yang dibuat Branch (2009).

Pada penelitian ini dibahas mengenai tahap analisis (analyze). Sampel dari penelitian ini adalah mahasiswa STKIP PGRI Sumatera Barat program studi pendidikan biologi dan pendidikan fisika yang sudah mengambil perkuliahan matematika dasar. Tahap analisis (analyze) ini dilakukan guna melihat gambaran kondisi di lapangan yang berkaitan dengan proses belajar mengajar. Proses yang dilakukan adalah menganalisis RPS, analisis sumber belajar, analisis kebutuhan mahasiswa berupa angket kebutuhan mahasiswa dan instrumen wawancara terhadap mahasiswa dan teman sejawat, dan analisis karakteristik mahasiswa. Hasil dari tahap analisis digunakan menjadi dasar pengembangan buku teks bilingual Matematika Dasar dengan pendekatan konstruktivisme.

Instrumen yang digunakan pada penelitian ini adalah lembar analisis RPS dan sumber belajar, angket, dan pedoman wawancara. Lembar analisis memuat pernyataan-pernyataan yang berkaitan dengan kelengkapan isi RPS dan sumber belajar, jika masih terdapat kekurangan akan disempurnakan sesuai dengan kebutuhan proses perkuliahan. Angket bertujuan untuk melihat tingkat kebutuhan mahasiswa terhadap buku teks bilingual pada mata kuliah matematika dasar. Pengisian angket menggunakan skala likert. Wawancara dilakukan pada mahasiswa dan teman sejawat. Untuk mewawancarai dibuat pedoman wawancara. Pedoman wawancara berisi tentang pertanyaan-pertanyaan tentang metode pembelajaran, kendala saat pembelajaran, dan mengenai bahan ajar. Sebelum digunakan, semua instrumen divalidasi oleh validator instrumen.

Teknik analisis data dari instrumen berupa angket analisis kebutuhan mahasiswa disusun dalam bentuk skala likert dengan pernyataan positif dan pernyataan negatif. Data hasil tanggapan mahasiswa dianalisis dengan langkah sebagai berikut.

a) Memberikan skor untuk setiap item jawaban, Sangat Setuju (4), Setuju (3), Cukup setuju (2), Tidak Setuju (1), dan Sangat Tidak Setuju (0), serta sebaliknya untuk item negatif.

b) Menjumlahkan skor total tiap mahasiswa untuk semua indikator.

c) Pemberian nilai analisis kebutuhan dengan menggunakan rumus rerata, kemudian rerata yang didapatkan dikonfirmasikan dengan kriteria yang ditetapkan, yakni sebagai berikut.

a) Bila $R>3,20$ maka buku teks dikategorikan sangat dibutuhkan.

b) Bila $2,40<R \leq 3,20$ maka buku teks dikategorikan dibutuhkan.

c) Bila $1,60<R \leq 2,40$ maka buku teks dikategorikan cukup dibutuhkan.

d) Bila $0,80<R \leq 1,60$ maka buku teks dikategorikan kurang dibutuhkan.

e) Bila $R \leq 0,80$ maka buku teks dikategorikan tidak dibutuhkan.

Data hasil analisis RPS, sumber belajar, serta wawancara dengan mahasiswa dan dosen mengenai kebutuhan terhadap buku teks bilingual Matematika Dasar digambarkan menggunakan teknik 
deskriptif. Miles dan Huberman (dalam Sugiyono, 2012) menyatakan "bahwa wawancara dari para pakar menghasilkan data kualitatif berdasarkan transkripsi tertulis dan catatan yang dibuat dibuat saat wawancara berlangsung". Cara menganalisis data kualitatif terdiri dari tiga tahap, yaitu mereduksi data, penyajian data, dan penarikan kesimpulan.

Tabel 1. Hasil Analisis RPS (Rencana Program Semester)

\begin{tabular}{|c|c|c|c|c|}
\hline \multirow{2}{*}{ No } & \multirow{2}{*}{ Aspek Penilaian } & \multirow{2}{*}{ Deskriptor } & \multicolumn{2}{|c|}{ Ketersediaan } \\
\hline & & & Ada & Tidak \\
\hline 1 & Identitas Mata Kuliah & $\begin{array}{l}\text { Memuat semua identitas (nama mata kuliah, kode, sks, } \\
\text { nama dosen pengampu mata kuliah, dan koordinator mata } \\
\text { kuliah, serta ketua program studi) }\end{array}$ & $\sqrt{ }$ & \\
\hline 2 & $\begin{array}{l}\text { Deskripsi Singkat } \\
\text { Mata Kuliah }\end{array}$ & Mencakup semua bahan kajian pembelajaran & $\sqrt{ }$ & \\
\hline \multirow[t]{6}{*}{3} & $\begin{array}{l}\text { Capaian Pembelajaran } \\
(\mathrm{CP})\end{array}$ & $\begin{array}{l}\text { a. Terdiri atas CP lulusan Program Studi (LO Prodi) dan CP } \\
\text { mata kuliah (LO mata kuliah) }\end{array}$ & $\sqrt{ }$ & \\
\hline & & b. CP lulusan relevan dengan visi dan misi program studi & $\sqrt{ }$ & \\
\hline & & $\begin{array}{l}\text { c. Rumusan CP mata kuliah sesuai dengan CP Program } \\
\text { Studi }\end{array}$ & $\sqrt{ }$ & \\
\hline & & $\begin{array}{l}\text { d. CP mata kuliah memuat semua indikator penilaian (sikap, } \\
\text { ketrampilan, dan pengetahuan) }\end{array}$ & $\sqrt{ }$ & \\
\hline & & $\begin{array}{l}\text { e. Ada kesesuaian antara CP matakuliah dengan indikator, } \\
\text { bahan kajian, bentuk pembelajaran, waktu, dan penilaian }\end{array}$ & $\sqrt{ }$ & \\
\hline & & f. Sesuai dengan karakteristik pembelajaran & $\sqrt{ }$ & \\
\hline 4 & Media Pembelajaran & $\begin{array}{l}\text { Media pembelajaran dapat membantu tercapainya CP mata } \\
\text { kuliah (yang berupa hardware dan software) }\end{array}$ & $\sqrt{ }$ & \\
\hline 5 & Mata Kuliah Prasyarat & $\begin{array}{l}\text { Merupakan syarat untuk mengambil mata kuliah } \\
\text { Matematika Dasar }\end{array}$ & & $\sqrt{ }$ \\
\hline \multirow[t]{4}{*}{6} & Bahan kajian & a. Materi pembelajaran benar secara teoritis & $\sqrt{ }$ & \\
\hline & & b. Materi pembelajaran selaran dengan CP mata kuliah & $\sqrt{ }$ & \\
\hline & & c. Materi pembelajaran runut/sistematis & $\sqrt{ }$ & \\
\hline & & d. Materi terinci & & $\sqrt{ }$ \\
\hline \multirow[t]{4}{*}{7} & Bentuk Pembelajaran & $\begin{array}{l}\text { a. Bentuk pembelajaran memuat aktivitas belajar yang } \\
\text { berpusat pada mahasiswa/belajar aktif }\end{array}$ & $\sqrt{ }$ & \\
\hline & & $\begin{array}{l}\text { b. Tahapan kegiatan pembelajaran mendukung tercapainya } \\
\text { CP mata kuliah }\end{array}$ & $\sqrt{ }$ & \\
\hline & & $\begin{array}{l}\text { c. Bentuk pembelajaran memberikan kesempatan kepada } \\
\text { siswa untuk mengembangkan kecakapan hidup (personal, } \\
\text { sosial) }\end{array}$ & $\sqrt{ }$ & \\
\hline & & $\begin{array}{l}\text { d. Sesuai dengan pengalaman belajar yang dikembangkan } \\
\text { dalam bentuk kegiatan pembelajaran }\end{array}$ & $\sqrt{ }$ & \\
\hline \multirow[t]{4}{*}{8} & Assesment/penilaian & $\begin{array}{l}\text { a. Rumusan indikator penilaian dapat mengukur tercapainya } \\
\text { CP mata kuliah }\end{array}$ & $\sqrt{ }$ & \\
\hline & & b. Rumusan indikator dapat diukur dan diobservasi & $\sqrt{ }$ & \\
\hline & & $\begin{array}{l}\text { c. Terdiri dari beberapa rumusan indikator untuk setiap CP } \\
\text { mata kuliah }\end{array}$ & $\sqrt{ }$ & \\
\hline & & d. Bobot yang diberikan sesuai dengan banyak bahan kajian & $\sqrt{ }$ & \\
\hline 9 & Estimasi Waktu & Estimasi waktu sesuai dengan cakupan CP mata kuliah & $\sqrt{ }$ & \\
\hline 10 & Norma Akademik & Norma akademik mendukung tercapainya $\mathrm{CP}$ mata kuliah & $\sqrt{ }$ & \\
\hline 11 & Nilai Akhir & Memuat seluruh aspek yang ada pada indikator penilaian & $\sqrt{ }$ & \\
\hline \multirow[t]{2}{*}{12} & Daftar kepustakaaan & $\begin{array}{l}\text { a. Sumber belajar sesuai untuk mendukung tercapainya } \\
\text { CP mata kuliah }\end{array}$ & $\sqrt{ }$ & \\
\hline & & b. Sumber belajar bervariasi & $\sqrt{ }$ & \\
\hline
\end{tabular}


Reduksi data merupakan suatu bentuk analisis yang menajamkan, menggolongkan, mengarahkan, membuang yang tidak perlu dan mengorganisasi data dengan cara sedemikian rupa sehingga dapat ditarik kesimpulan. Reduksi data atau proses transformasi data akan terus berlanjut setelah penelitian di lapangan sampai laporan tersusun dengan lengkap. Penyajian data merupakan sekumpulan informasi yang tersistematis kemungkinan adanya penarikan kesimpulan dan pengambilan tindakan. Dengan melihat penyajianpenyajian akan dapat dipahami apa yang sedang terjadi dan apa yang harus dilakukan. Penarikan kesimpulan dirumuskan dari kegiatan yang dilakukan selama penelitian berlangsung. Dalam hal ini kesimpulan akan menyatakan tingkat kepraktisan produk yang sudah dihasilkan dan diuji cobakan.

\section{HASIL DAN PEMBAHASAN Hasil Analisis RPS}

Hasil analisis RPS tertuang pada Tabel 1. Menurut Tabel 1 diperoleh bahwa RPS sudah memuat hampir semua aspek yang dibutuhkan dalam pembelajaran matematika dasar untuk satu semester, yang belum termuat adalah materi prasyarat. Pada aspek bahan kajian materi belum dijelaskan secara rinci, sehingga perlu dirincikan lagi. Namun secara garis besar RPS sudah disusun sesuai dengan peraturan Menteri Pendidikan dan Kebudayaan Nomor 49 tahun 2014 tentang Standar asional Pendidikan Tinggi dan diperbaharui dengan Peraturan Menteri Riset Teknologi dan Pendidikan Tinggi Nomor 44 tahun 2015 tentang standar nasional Pendidikan Tinggi. RPS yang disusun paling sedikit memuat: 1) nama program studi, nama kode mata kuliah, semester, SKS, dan nama dosen pengam$\mathrm{pu}$; 2) capaian pembelajaran lulusan yang dibebankan pada mata kuliah; 3) kemampuan akhir yang direncanakann pada tiap tahap pembelajaran untuk memenuhi capaian pembelajaran lulusan; 4) bahan kajian yang terkait dengan kemampuan yang akan dicapai; 5) metode pembelajaran; 6) waktu yang disediakan untuk mencapai kemampuan pada tiap tahap pembelajaran; 7) pengalaman belajar mahasiswa yang diwujudkan dalam deskripsi tugas yang harus dikerjakan mahasiswa selama satu semester; 8) kriteria, indikator, dan bobot penilaian; serta 9) daftar referensi yang digunakan.

\section{Hasil Analisis Sumber Belajar}

Berdasarkan hasil analisis sumber belajar pada Tabel 2, perlu dirancang buku dengan judul sesuai pencapaian $\mathrm{CP}$, artinya buku akan dirancang sesuai dengan materi yang dibutuhkan pada mata kuliah Matematika Dasar. Materi dalam buku akan disusun secara runtut dan sesuai dengan $\mathrm{CP}$, urutan materi akan memperhatikan urutann seperti yang terdapat dalam RPS. Buku akan dibuat memuat pendahuluan bab yang berkaitan dengan masalah kontekstual dan terkait dengan aplikasi materi tersebut dalam kehidupan nyata, sehingga buku dapat memberikan motivasi kepada mahasiswa untuk mempelajarinya lebih lanjut. Buku juga akan dirancang memuat aktivitas atau kegiatan-kegiatan yang dapat membuat mahasiswa belajar aktif baik secara 
mandiri ataupun berkelompok, sehingga mereka dapat mengkonstruksi pengetahuannya dengan pengetahuan yang sudah ada sebelumnya. Kemudian, buku akan dirancang memuat soal-soal latihan dan tugas yang dapat memfasilitasi dosen untuk melakukan penilaian pengetahuan, sikap, dan keterampilan.

Tabel 2. Hasil Analisis Sumber Belajar

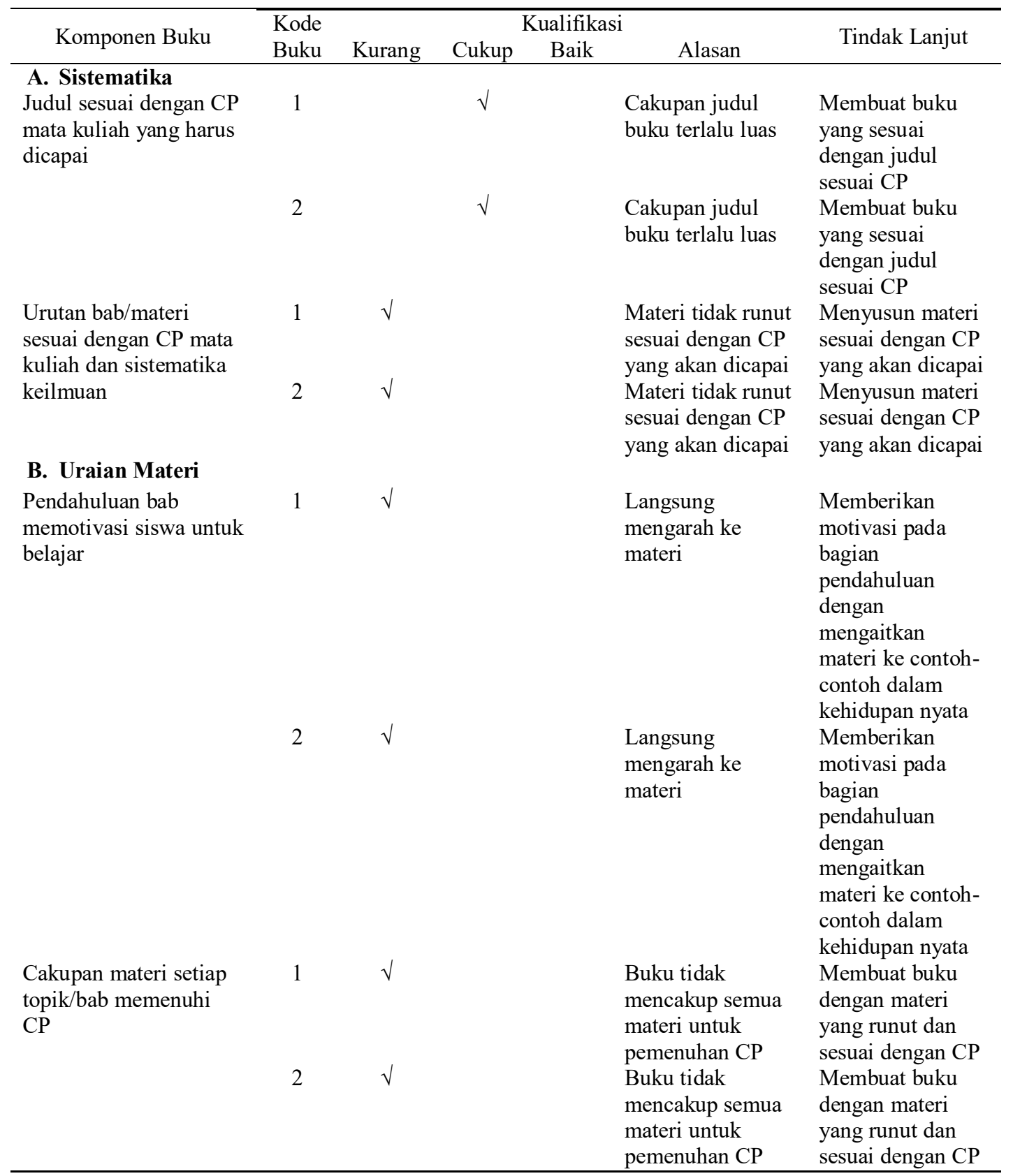




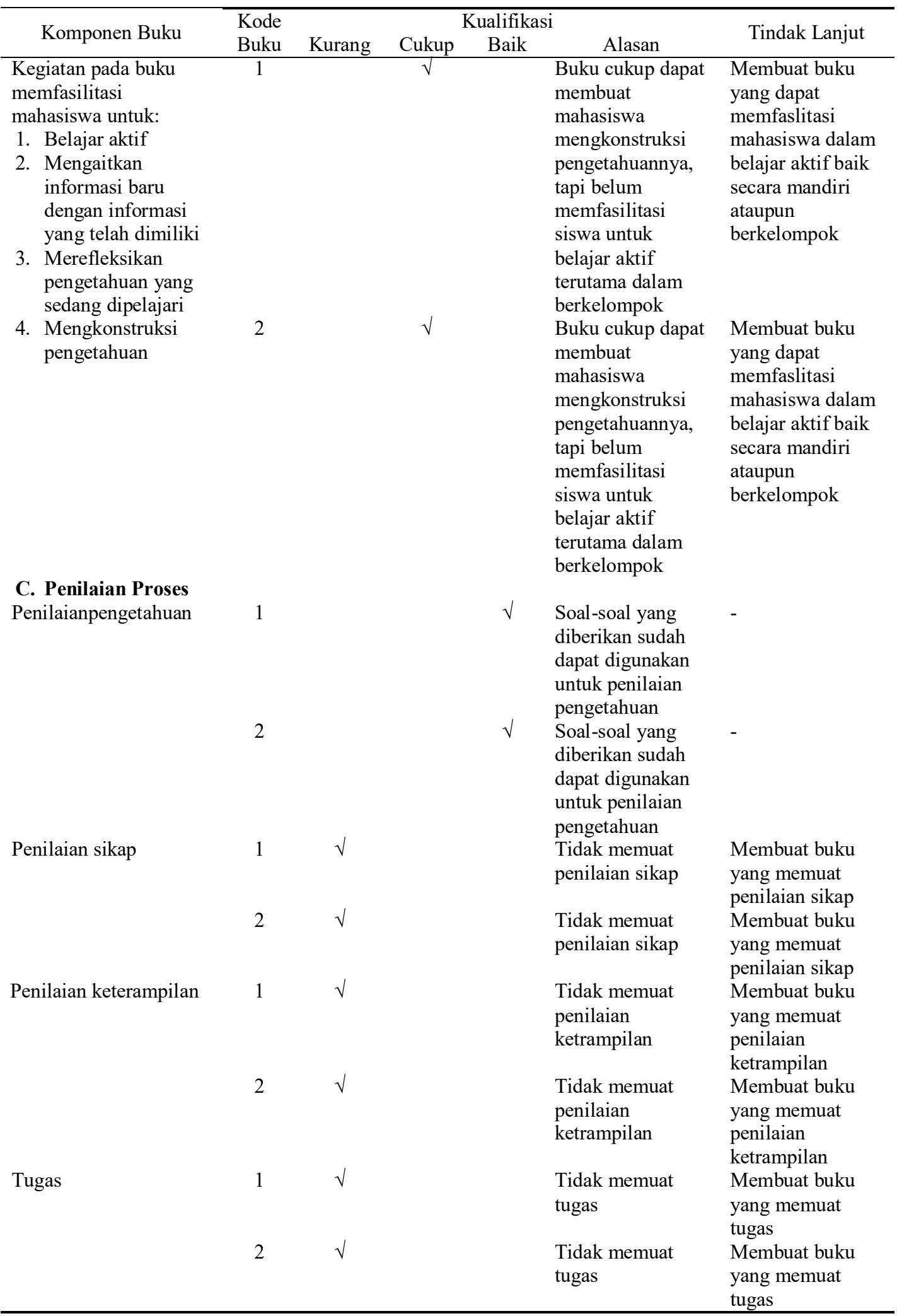




\section{Hasil Analisis Kebutuhan Mahasiswa Berupa Angket Kebutuhan Maha- siswa}

Angket yang diberikan kepada mahasiswa berisi pernyataan-pernyataan tentang kebutuhan mahasiswa akan buku teks. Angket terdiri atas 20 item pernyataan dengan menggunakan skala likert.

Angket analisis kebutuhan diberikan kepada mahasiswa, diperoleh hasil reratanya adalah 2,7, maka dapat dikategorikan pada bahan ajar dibutuhkan. Karena bahan ajar yang digunakan dalam perkuliahan matematika dasar selama ini masih terbatas, belum mencakup keseluruhan materi, belum bisa membangun pengetahuan mahasiswa, tidak memfasilitasi mahasiswa dalam belajar kelompok, belum memuat masalah konteks dalam kehidupan sehari-hari dan belum ada yang berbahasa Inggris.

\section{ANGKET KEBUTUHAN MAHASISWA}

Angket ini merupakan angket yang mendeskripsikan kebutuhan Anda akan bahan ajar. Ini bukan tes, Anda boleh berpendapat sesuai dengan yang Anda inginkan.

\begin{tabular}{lll}
\hline Pilihan & Angka & Keterangan \\
\hline STS & 0 & Sangat Tidak Setuju \\
TS & 1 & Tidak Setuju \\
CS & 2 & Cukup Setuju \\
ST & 3 & Setuju \\
SS & 4 & Sangat Setuju \\
\hline
\end{tabular}

Angket ini terdiri dari 20 butir pernyataan. Untuk masing-masing pernyataan, ceklis nomor untuk menunjukkan pendapat Anda. Contohnya:

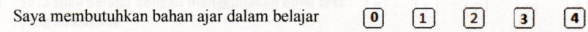

Jika Anda pikir sangat membutuhkan bahan ajar ceklis (4). Jika Anda pikir sangat tidak membutuhkan bahan ajar ceklis 0 . Anda juga dapat memilih nomor 11,2 , dan 3 yang ada diantaranya. Jika Anda ingin mengganti jawaban Anda, silang nomor tersebut dan ceklis nomor yang baru. Terima kasih untuk kerjasama Anda.

Gambar 1. Angket Kebutuhan Mahasiswa Halaman 1

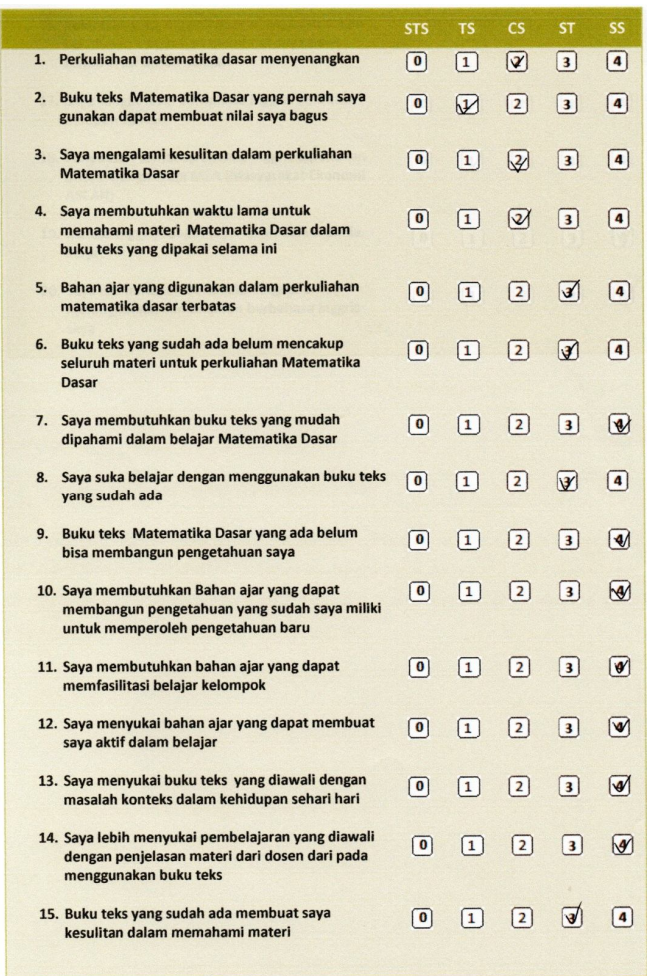

Gambar 2. Angket Kebutuhan Mahasiswa Halaman 2

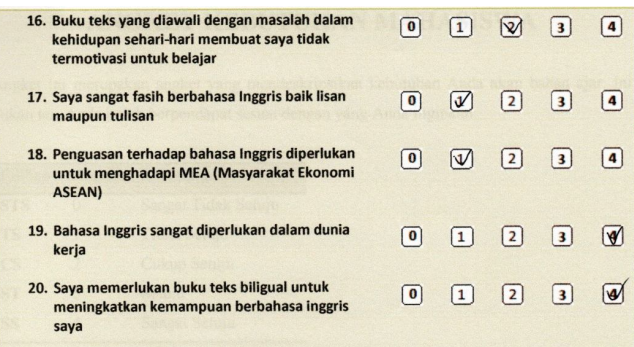

Gambar 3. Angket Kebutuhan Mahasiswa Halaman 3

\section{Hasil Wawancara terhadap Maha- siswa dan Teman Sejawat}

Ada tujuh aspek yang termuat dalam pedoman wawancara, yaitu: 1) bagaimana proses perkuliahan, 2) kendala yang dihadapi mahasiswa dalam perkuliahan, 3) waktu yang dibutuhkan mahasiswa dalam memahami materi pelajaran, 4) bahan ajar yang digunakan mahasiswa dalam pembelajaran, 5) pan- 
dangan mahasiswa terhadap bahan ajar yang digunakan, 6) karakteristik bahan ajar yang diharapkan mahasiswa, dan 7) pandangan mahasiswa terhadap bahan ajar bilingual berbasis konstruktivisme. Tujuh aspek ini dijabarkan menjadi 13 item pertanyaan.

Hasil wawancara dengan teman sejawat menunjukkan bahwa proses perkuliahan matematika dasar dengan menggunakan metode ceramah, metode ekspositori, dan metode kelompok. Kendala yang ditemukan dalam proses pembelajaran yaitu ketika menerapkan pembelajaran berkelompok karena kemampuan mahasiswa yang heterogen dan kebanyakan berkemampuan rendah, sehingga mahasiswa mengalami kesulit- an dalam memahami materi perkuliahan apalagi jika mereka diminta untuk belajar mandiri. Sebelumnya mahasiswa hanya menerima penjelasan dari dosen saja tanpa ada usaha terlebih dahulu dari diri mahasiswa itu sendiri. Di samping itu mahasiswa hanya menggunakan bahan ajar yang dimiliki dosen, mereka tidak ada berusaha mencari buku sumber yang lain. Oleh sebab itu, dikembangkan buku teks bilingual dengan menggunakan pendekatan konstruktivisme. Dosen belum pernah mencoba menggunakan pendekatan konstruktivisme, karena pendekatan kosntruktivisme dapat mengkonstruk pemikiran mahasiswa dalam memahami materi perkuliahan sehingga pembelajaran bisa lebih efektif

Tabel 3. Analisis Karakteristik Mahasiswa

\begin{tabular}{|c|c|c|c|c|c|}
\hline \multirow{2}{*}{$\begin{array}{c}\text { Karakteristik } \\
\text { Mahasiswa } \\
\text { yang } \\
\text { Dianalisis }\end{array}$} & \multicolumn{2}{|c|}{ Kualifikasi } & \multirow{2}{*}{$\begin{array}{c}\text { Deskripsi } \\
\text { Karakteristik } \\
\text { Mahasiswa }\end{array}$} & \multirow[b]{2}{*}{ Alasan } & \multirow[b]{2}{*}{ Tindak Lanjut } \\
\hline & Kurang & Baik & & & \\
\hline Motivasi & $\sqrt{ }$ & & $\begin{array}{l}\text { Mahasiswa tidak } \\
\text { memiliki motivasi } \\
\text { dalam belajar } \\
\text { matematika }\end{array}$ & $\begin{array}{l}\text { Ketersedian buku } \\
\text { yang terbatas, buku } \\
\text { yang ada belum bisa } \\
\text { menumbuhkan } \\
\text { motivasi mahasiswa } \\
\text { dalam belajar }\end{array}$ & $\begin{array}{l}\text { Mengembangkan buku } \\
\text { yang dapat } \\
\text { menumbuhkan motivasi } \\
\text { belajar mahasiswa }\end{array}$ \\
\hline Cara belajar & $\sqrt{ }$ & & $\begin{array}{l}\text { Mahasiswa } \\
\text { mempunyai } \\
\text { ketergantungan } \\
\text { yang besar pada } \\
\text { dosen dalam } \\
\text { belajar }\end{array}$ & $\begin{array}{l}\text { Sumber belajar } \\
\text { masih kurang, } \\
\text { sehingga } \\
\text { menimbulkan } \\
\text { ketergantungan yang } \\
\text { besar pada dosen } \\
\text { dalam belajar }\end{array}$ & Mengembangkan buku \\
\hline $\begin{array}{l}\text { Pemahaman } \\
\text { konsep }\end{array}$ & $\sqrt{ }$ & & $\begin{array}{l}\text { Pemahaman } \\
\text { konsep mahasiswa } \\
\text { terhadap materi } \\
\text { yang dipelajari } \\
\text { masih kurang }\end{array}$ & $\begin{array}{l}\text { Sumber belajar } \\
\text { masih kurang dan } \\
\text { ketergantungan pada } \\
\text { dosen masih tinggi }\end{array}$ & $\begin{array}{l}\text { Mengembangkan buku } \\
\text { yang bisa } \\
\text { mengkonstruksi } \\
\text { pemahaman konsep } \\
\text { mahasiswa }\end{array}$ \\
\hline Kemandirian & $\sqrt{ }$ & & $\begin{array}{l}\text { Mahasiswa masih } \\
\text { belum mandiri } \\
\text { dalam belajar }\end{array}$ & $\begin{array}{l}\text { Sumber belajar } \\
\text { masih kurang dan } \\
\text { ketergantungan pada } \\
\text { dosen masih tinggi }\end{array}$ & $\begin{array}{l}\text { Mengembangkan buku } \\
\text { yang dapat } \\
\text { menumbuhkan } \\
\text { kemandirian mahasiswa } \\
\text { dan membangun } \\
\text { pengetahuan baru } \\
\text { tentang materi yang } \\
\text { dipelajari }\end{array}$ \\
\hline
\end{tabular}


dan mahasiswa aktif dalam belajar. Secara tidak langsung buku teks bilingual juga dapat menambah kosakata dalam memahami bahasa Inggris.

Hasil wawancara dengan mahasiswa menunjukkan bahwa selama ini proses pembelajaran matematika dasar hanya menggunakan satu modul yang dibuat oleh dosen. Masih terdapat materi yang sulit untuk dipahami karena soal yang terdapat dalam modul belum variatif. Mahasiswa membutuhkan bahan ajar yang memuat banyak contoh soal dan latihan. Oleh karena itu, mahasiswa membutuhkan bahan ajar lain sebagai alternatif sumber belajar yang dapat membantu membangun pengetahuan baru.

Hasil wawancara dengan teman sejawat dan mahasiswa dapat disimpulkan bahwa buku teks juga dibutuhkan untuk menambah wawasan mahasiswa dan disesuaikan dengan perkembangan zaman, sehingga dikembangkanlah buku teks bilingual matematika dasar dengan pendekatan konstrukstivisme dengan tujuan dapat mengkonstruks pemikiran mahasiswa sehingga mahasiswa tidak perlu menghafal rumus lagi, dan pembelajaran dapat lebih bermakna dan tahan lama.

\section{Analisis Katakteristik Mahasiswa}

Berdasarkan hasil analisis karakteristik mahasiswa pada Tabel 3, dapat disimpulkan bahwa buku yang dapat menumbuhkan motivasi, dan menumbuhkan kemandirian mahasiswa dalam belajar, adalah buku yang dapat mengkonstruksi konsep sehingga mahasiswa dapat membangun pengetahuan baru dari pengetahuan yang sudah ada sebelum- nya. Sesuai dengan teori-teori yang sudah dipaparkan sebelumnya, maka buku yang tepat untuk mencapai tujuan tersebut adalah buku teks berbasis konstruktivisme. Di samping dapat mengkonstruksi konsep dan membangun pengetahuan yang baru mahasiswa juga dapat menambah keterampilan mahasiswa dalam berbahasa Inggris buku dibuat dengan menggunakan dua bahasa (bilingual), bahasa Indonesia dan Bahasa Inggris.

\section{PENUTUP}

Berdasarkan hasil analisis kebutuhan dapat disimpulkan bahwa mahasiswa membutuhkan suatu bahan ajar dalam perkuliahan matematika dasar, yakni bahan ajar yang mampu mengkonstruksi pengetahuan mereka untuk memahami konsep berdasarkan pengetahuan yang sudah ada sebelumnya, sekaligus dapat meningkatkan kempampuan berbahasa Inggris. Bahan ajar yang dimaksud adalah buku teks Matematika Dasar bilingual berbasis konstruktisme. Dalam mengembangkan buku teks haruslah memperhatikan kesesuaian judul dengan pencapaian $\mathrm{CP}$, kesesuaian materi dengan $\mathrm{CP}$, memuat materi yang runut, memuat pendahuluan bab yang dapat memberikan motivasi kepada mahasiswa, dapat menciptakan belajar yang aktif dan dapat mengkonstruksi pengetahuan mahasiswa, serta memuat penilaian pengetahuan, sikap, keterampilan dan tugas. 


\section{DAFTAR PUSTAKA}

Altbach, P. G., Kelly, G. P., Petrie, H. G., \& Weis, L. (1991). Textbooks in American society: Politics, policy, and pedagogy. SUNY Press.

Ansary, H., \& Babaii, E. (2002). Universal characteristics of EFL/ESL textbooks: A step towards systematic textbook evaluation. The Internet TESL Journal, 8(2), 1-9.

Barlia, L. (2011). Konstruktivisme Dalam Pembelajaran Sains di SD: Tinjauan Epistemologi, Ontologi, dan Keraguan Dalam Praksisnya. Jurnal Cakrawala Pendidikan, $3(3)$.

Branch, R. M. (2009). Instructional design: The ADDIE approach (Vol. 722). Springer Science \& Business Media.

Depdiknas. (2007). Panduan Penyelenggaraan SMP Bertaraf Internasional. Jakarta: Dit.PSMP.

Driver, R., \& Oldham, V. (1986). A constructivist approach to curriculum development in science.
Hamdunah, H., Yunita, A., Zulkardi, Z., \& Muhafzan, M. (2016). Development a constructivist module and web on circle and sphere material with Wingeom software. Journal on Mathematics Education, 7(2), 109-116.

Murtiyasa, B. (2015). Tantangan pembelajaran matematika era global. Prosiding Seminar Nasional Matematika dan Pendidikan Matematika UMS (2847). Surakarta: Universitas Muhamadiyah Surakarta.

Muslich, M. (2008). Fonologi Bahasa Indonesia: Tinjauan Deskriptif Sistem Bunyi Bahasa Indonesia. Bumi Aksara.

Sugiyono. (2012). Metode Penelitian Pendidikan. Bandung: $\quad \mathrm{CV}$ Alfabeta.

Supriyadi, E. (2012). Pembelajaran Secara Bilingual Di Jurusan Pendidikan Teknik Elektro. Cakrawala Pendidikan, (2).

Wikipedia. (2017, Juli 30). Billingual Education. Diambil dari www.id.wikipedia.org/bilingual 